\title{
EKSISTENSI SANIRI DALAM PEMERINTAHAN NEGERI SULI KECAMATAN SALAHUTU KABUPATEN MALUKU TENGAH
}

\author{
Pieter S. Soselisa, Ivonny Y. Rahanra, Wahyu F. Chaniago, Rugayah Alhamid \\ Program Studi Administrasi Publik Fakultas Ilmu Sosial dan Ilmu Politik \\ Universitas Pattimura \\ soselisapieter5@gmail.com, ivonny.rahanra@gmail.com, \\ wahyufatimahmpa@gmail.com, gayaalhamid@gmail.com
}

\begin{abstract}
Abstrak
Saniri negeri merupakan lembaga yang sudah ada sejak lama dalam sistem pemerintahan negeri terutama di negerinegeri adat (desa) di Maluku. Sebagai lembaga adat Saniri Negeri merupakan representase masyarakat negeri yang juga berfungsi menyuarakan aspirasi masyarakat. Saniri negeri juga mitra dari pemerintah negeri dalam merencanakan dan menyusun program yang akan dilakukan di dalam negeri berdasarkan kebutuhan masyarakat dan negeri itu sendiri. Pemberlakuan UU nomor 5 tahun 1979 tentang Pemerintah desa yang menyeragamkan sistem pemerintahan desa di seluruh Indonesia, telah merubah nilai-nilai budaya yang menyangkut adat istidat yang dianut dan membawa pengaruh terhadap keberadaan adat istiadat seperti halnya negeri di Maluku, termasuk kelembagaan Saniri. Namun dengan pemberlakuan UU no 32 Tahun 2004, yang memberikan ruang bagi daerah-daerah di Indonesia termasuk Provinsi Maluku yang kemudian ditindak lanjuti dengan dikeluarkannya Peraturan Daerah Nomor 14 Tahun 2004 tentang Penetapan kembali Negeri sebagai kesatuan masyarakat Hukum Adat dalam wilayah Pemerintahan Provinsi Maluku.beserta masyarakat adatnya yang dapat menerapkan lagi dalam sistem pemerintahan yang sudah ada sejak dulu. Keberadaan Saniri Negeri diharapkan dapat menjalankan peranannya selain sebagai lembaga adat yang sudah ada sejak dulu juga saat ini sebagai bagian dan mitra dari pemerintah negeri untuk bersama-sama menjalankan pemerintahan di negeri demi kesejahteraan masyarakat. Eksistensi Saniri Negeri diharapkan dapat memainkan peran lebih karena saat ini telah ada Peraturan Daerah yang khusus tentang Saniri Negeri, termasuk di lokasi studi Negeri Suli yang mengacu pada Peraturan Daerah Kabupaten Maluku Tengah Nomor 04 Tahun 2006 tentang Pedoman Penataan Saniri Negeri atau Badan Permusyawaratan Negeri. Dengan adanya Peraturan Daerah tersebut Saniri Negeri lebih mengetahui kedudukannnya, serta dapat melakukan peranan, fungsi dan kewenangannya dalam pemerintahan negeri.
\end{abstract}

Kata Kunci: Eksistensi, Peranan dan Saniri Negeri.

Saniri Negeri is an institution that has existed for a long time especially in customary villages in Maluku. As a traditional institution, Saniri Negeri is a representative of people which also functions to voice the aspirations of the community. Saniri Negeri is also a partner of the state government in planning and compiling programs to be carried out in the country based on the needs of the community and the country itself. Law number 5 of 1979 concerning village government which uniform village government systems throughout Indonesia, has changed cultural values concerning the customs adopted and has an influence on the existence of customs such as the country in Maluku, including the Saniri institution. However, with the enactment of Law No. 32 of 2004, which provided space for regions in Indonesia including Maluku Province which was then followed up by the issuance of Regional Regulation No. 14 of 2004 concerning Reestablishment of the Country as a customary law community unit within the Maluku Provincial Government area. custom which can be applied again in the government system that has existed since long ago. The existence of Saniri Negeri is expected to be able to carry out its role in addition to being a traditional institution that has existed for a long time as well as now as part and partner of the state government to jointly run the government in the country for the welfare of the community. It is hoped that the existence of Saniri Negeri will play a greater role because currently there is a special Regional Regulation on Saniri Negeri, including in the study location of the State of Suli which refers to the Regional Regulation of Central Maluku Regency Number 04 of 2006 concerning Guidelines for Saniri Negeri Structuring or the Village Consultative Body. With the existence of this Regional Regulation, Saniri Negeri knows more about its position and can carry out its role, function and authority in the government of the country.

Keywords: Existence, Role and Saniri Negeri. 


\section{Pendahuluan.}

Negara Indonesia adalah negara kesatuan yang berbentuk republik yang dalam penyelenggaraan pemerintahannya terdiri atas wilayah provinsi, kabupaten/kota, kecamatan sampai ke wilayah perdesaan. Penyelenggaraan pemerintahan sangat berperan dalam menata kelola berbagai kegiatan pembangunan, sehingga untuk mencapai hasil pembangunan diharapkan peran penyelenggara pemerintahan di berbagai tingkatan terutama wilayah perdesaan.

Sebagai bagian dari pemerintahan di Indonesia desa memiliki hak asal usul dan hak tradisional dalam mengatur dan mengurus kepentingan masyarakat. Ini membutuhkan pemerintahan desa yang cakap dan tanggap dalam mengatasi serta menyelesaikan berbagai persoalan maupun permasalahan yang ada di desa. Persoalan di desa tidak hanya menyangkut sumberdaya manusia saja, tetapi juga sumberdaya alam, sumberdaya sosial dan budaya, bahkan persoalan sumberdaya antara desa satu dengan desa lainnya.

Pemerintah desa diharapkan dapat memberdayakan segenap sumberdaya serta mengajak berbagai unsur di desa bekerja bersama-sama demi mensejahterakan masyarakatnya sesuai dengan kewenangan yang dimilikinya. Berdasarkan pasal 18 UU Nomor 6 Tahun 2014 tentang Desa, kewenangan desa ini meliputi kewenangan di bidang penyelenggaraan pemerintah desa, pelaksanaan pembangunan desa, pembinaan kemasyarakatan desa, dan pemberdayaan masyarakat desa berdasarkan prakarsa masyarakat, hak asal usul dan adat istiadat desa

Dengan kewenangan yang ada Pemerintah desa sangat diperlukan dengan penataan administrasi yang baik dan benar, sehingga dalam menyusun perencanaan progam pembangunan. Pembangunan desa ini meliputi perencanaan, pelaksanaan dan pengawasan, yang ketiganya merupakan siklus berkesinambungan satu dengan lainnya serta melibatkan masyarakat didalamnya. Masyarakat desa berhak melakukan pemantauan terhadap pelaksanaan pembangunan desa. Sehingga program pembangunan yang dilaksanakan benar-benar dapat menjawab berbagai permasalahan yang dihadapi yang hasilnya dapat dirasakan oleh segenap masyarakat untuk kemajuan dan kesejahteraan desa.

Provinsi Maluku dengan pemberlakuan Undang-Undang Nomor 32 Tahun 2004 menginginkan agar negeri-negeri beserta masyarakat adatnya yang sudah ada sejak dulu dapat menerapkan lagi dalam sistem pemerintahan yang sudah ada sejak dulu di Maluku. Hal ini harus dilakukan karena Pemberlakuan Undang-Undang Nomor 5 Tahun 1979 telah 
merubah nilai-nilai budaya yang menyangkut adat istidat yang dianut dan membawa pengaruh terhadap keberadaan adat istiadat seperti Negeri di Maluku, karena hukum adat yang tadinya digunakan dalam pemerintahan menjadi hilang dan diganti dengan sistem Pemerintahan Desa yang yang diberlakukan secara umum untuk seluruh pemerintahan desa. Struktur masyarakat hukum adat yang dulunya sangat kuat dan dijalankan dalam pemerintahan, hukum maupun sosial budaya kemasyarakatan menjadi kurang berperan bahkan cenderung hilang atau tidak dilaksanakan lagi. Kebiasaan-kebiasaan dan keputusan-keputusan yang biasanya diambil berdasarkan norma adat menjadi terabaikan dan tidak dikenal selama beberapa generasi yang menyebabkan adanya kekhwatiran kehilangan daya berlakunya.

Demikian halnya dengan Saniri Negeri sebagai lembaga pemerintahan yang telah ada sejak dulu dan merupakan bagian dari sistem pemerintahan pada negeri-negeri di Maluku juga terkena dampaknya meskipun tidak semua negeri yang mengabaikannya atau melupakannya namun banyak negeri-negeri yang tidak menjalankan kelembagaan Saniri Negeri sesuai fungsi dan peranannya secara optimal bahkan ada negeri-negeri yang sama sekali tidak memfungsikan kelembagaan Saniri Negeri ini (Soselisa P.S : 2010)

Pemberlakuan Undang-Undang Nomor 32 Tahun 2004 diharapkan dapat memfungsikan kembali kelembagaan-kelembagaan adat yang sudah atau pernah berlaku di negeri-negeri/desa-desa di Maluku secara optimal dan ini ditindak lanjuti dengan dikeluarkannya Peraturan Daerah Nomor 14 Tahun 2004 tentang Penetapan kembali Negeri sebagai kesatuan masyarakat Hukum Adat dalam wilayah Pemerintahan Provinsi Maluku. Ini juga memberikan dasar hukum yang kuat untuk dapat dijadikan pijakan bagi negeri-negeri adat untuk dapat memfungsikan lagi kelembagaan-kelembagaan adat yang sudah ada sejak dulu atau terkena dampak peranannya dengan pemberlakukan UndangUndang Nomor 5 Tahun 1979. Kelembagaan Saniri negeri selama ini memang tidak pernah dihapuskan atau dihilangkan dalam sistem pemerintahan negeri-negeri adat di Maluku, namun akibat pemberlakukan Undang-Undang Nomor 5 Tahun 1979 yang menyeragamkan sistem pemerintah desa untuk seluruh wilayah Kesatuan Republik Indonesia mengakibatkan kelembagaan Saniri negeri ini mengalami kemerosotan peran dan fungsinya sebagai lembaga yang telah ada dan berlaku sejak dulu. Untuk itu dengan berlakunya Undang-Undang Nomor 32 Tahun 2004 diharapkan kelembagaan Saniri Negeri benar-benar dapat memfungsikan perannya sesuai dengan yang telah dilakukan sejak dulu. 
Pemerintah Maluku Tengah berdasarkan Perda Nomor 14 Tahun 2004 kemudian ditindak lanjuti dengan dikeluarkannya Peraturan Daerah Kabupaten Maluku Tengah Nomor 01 Tahun 2006 tentang Negeri. Negeri sebagai kesatuan masyarakat hukum adat dalam kenyataannnya sejak dari dahulu kala hingga saat ini masih terus hidup, tumbuh, berkembang dan dipertahankan di dalam pergaulan hidup masyarakat di Kabupaten Maluku Tengah. Negeri merupakan kesatuan masyarakat hukum adat yang bersifat geneologis teritorial yang memiliki batas wilayah berwenang mengatur dan mengurus kepentingan masyarakat setempat berdasarkan hak asal usul dan adat istiadat setempat.

Negeri dipimpin oleh seorang kepala pemerintahan dengan gelar Raja atau disebut dengan nama lain sesuai adat istiadat, hukum adat dan budaya setempat. Jabatan Kepala Pemeintahan Negeri merupakan hak dari mata rumah/keturunan tertentu berdasarkan garis keturunan lurus atau tidak dapat dialihkan kepada pihak lain, kecuali dalam hal-hal khusus yang ditetapkan berdasarkan hasil musyawarah matarumah/keturunan yang berhak bersama Saniri Negeri (Perda Kabupaten Maluku Tengah Nomor 01 Tahun 2006).

Saniri Negeri dibentuk untuk menunjang penyelenggaraan pemerintahan Negeri berkedudukan sebagai unsur penunjang penyelenggaraan pemerintah Negeri dan mitra kerja kepala pemerintahan yang berfungsi menetapkan peraturan Negeri, serta menampung dan menyalurkan aspirasi masyarakat. Saniri Negeri juga berfungsi untuk menjaga, memelihara, mengayomi dan melestarikan adat istiadat, hukum adat dan budaya masyarakat di lingkungannya yang hidup, tumbuh dan berkembang.

Sebagai lembaga yang dalam penyelenggaraan Pemerintahan Negeri merupakan perwujudan demokrasi di negeri Saniri Negeri berfungsi sebagai badan legislatif yang selain membentuk peraturan negeri bersama-sama kepala Pemerintahan Negeri, juga mengawasi pelaksanaan tugas dari Kepala pemerintahan Negeri. Tugas dan wewenang yang dimiliki Saniri Negeri mempunyai peranan penting dalam penyelenggaraan pemerintahan negeri. Saniri Negeri diharapkan mampu menyerap, menampung maupun menyalurkan aspirasi masyarakat. Selain itu juga dapat melakukan kerja sama yang efektif dengan pemerintah negeri untuk mengeluarkan peraturan negeri yang dapat menjawab kebutuhan masyarakat secara keseluruhan.

Kenyataan menujukkan bahwa Saniri negeri Suli Kabupaten Maluku tengah ini belum melaksakan tugas, kewenangan seperti yang diamatkan oleh Undang-Undang maupun Peraturan Daerah yang telah dikeluarkan secara optimal. Belum adanya 
pemerintah negeri yang definitif serta masa tugas dari Saniri itu sendiri menjadi faktor yang turut mempengaruhi eksistensi Saniri Negeri itu sendiri.

\section{Metode Penelitian.}

Metode yang digunakan dalam studi ini didasarkan pada metode kualitatif yang menunjuk pada prosedur-prosedur riset yang menghasilkan data kualitatif, untuk memahami masyarakat secara personal dan memandang mereka sebagaimana mereka sendiri mengungkapkan pandangan mereka, menangkap pengalaman-pengalaman mereka dalam aktivitas mereka sehari-hari dan mengkaji pengalaman yang sama sekali belum kita ketahui (Moleong ; 2006).

Penelitian ini dilakukan di Negeri Suli Kecamatan Salahutu, Kabupaten Maluku Tengah. Pengumpulan data dilakukan melalui observasi dan wawancara. Pengamatan dilakukan untuk mengetahui keadaan yang sebenarnya guna menjawab permasalahan sesuai kebutuhan data yang diperlukan. Informan yang dipilih dalam studi ini mencakup aparat pemerintah negeri, anggota Saniri Negeri dan unsur dalam masyarakat dari pemuda dan tokoh masyarakat. Data yang berhasil dikumpulkan kemudian diolah, dianalisa dan diinterpretasi. Selain data primer, dikumpulkan pula sejumlah data sekunder khususnya yang terkait atau relevan dengan permasalahan yang diteliti. Data primer berupa pendapat, informasi, persepsi dan pemikiran dari informan yang terkait langsung maupun tidak langsung dengan permasalahan dalam penelitian. Dan data sekunder yang terdiri dari dokumen-dokumen, laporan-laporan dan catatan yang diperoleh pada lokasi penelitian.

Data yang diperoleh kemudian dianalisis dengan merujuk pada teknik analisa Miles dan Huberman (1992:16-20) yang berlangsung melalui tiga alur kegiatan, yaitu reduksi data, penyajian data, dan penarikan kesimpulan atau verifikasi. Teknik triangulasi, baik triangulasi sumber maupun teknik dipergunakan sebagai teknik pemeriksaan keabsahan data.

\section{Temuan dan Pembahasan.}

\subsection{Saniri Negeri}

Dalam sistem budaya Maluku konsep sistem pemerintahan yang berasal dan berpedoman pada sistem pemerintahan yang telah dilakukan sejak dahulu secara turun temurun dengan berbagai aturan-aturan serta kegunaannya. Saniri Negeri merupakan sebuah lembaga dalam pemerintah negeri yang sudah ada sejak dulu dalam pemerintah 
negeri di negeri-negeri adat di Maluku. Saniri Negeri yang disebut juga Saniri Lengkap, keanggotaannya terdiri dari pejabat-pejabat yang duduk di Saniri RajaPatti dan wakilwakil dari soa-soa tetapi bukan kepala soa, kepala-kepala adat, dan tua-tua negeri seperti kepala-kepala soa tanah, tukang (tukang disini bukan sekedar pandai, seperti tukang besi, tukang kayu, tetapi orang yang mengawasi pembangunan, misalnya masjid, gereja, sekolah dan lain-lain di bidang pembangunan fisik), para cendekiawan, kewang darat dan kewang laut, dan petugas-petugas dibidang kerohanian, dimana jumlah keanggotaan Saniri ini biasanya $12-15$ orang. Tentang hal-hal penting yang akan dilakukan di dalam negeri, maka pemerintah negeri harus lebih dulu meminta persetujuan Saniri Negeri (Effendi.Z, $1986: 43$ ).

Eksistensi Saniri Negeri harus lebih menunjukkan perannya, dimana Saat ini Saniri Negeri adalah Lembaga/Badan yang merupakan perwujudan demokrasi dalam penyelenggaraan Pemerintah Negeri, dan berfungsi sebagai Badan Legislatif yang bersama-sama Kepala Pemerintahan Negeri membentuk Peraturan Negeri, mengawasi pelaksanaan tugas dari Kepala Pemerintahan Negeri, memberikan masukan-masukan, pertimbangan-pertimbangan, nasehat-nasehat, juga memberi teguran kepada pemerintah negeri bila pemerintah negeri melaksanakan kebijakan yang dianggap tidak sesuai dengan program atau kepentingan negeri.

Dalam Peraturan Daerah Kabupaten Maluku Tengah Nomor 04 Tahun 2006 yang didasarkan atas persetujuan bersama Dewan Perwakilan Rakyat Daerah Kabupaten Maluku Tengah dan Bupati Maluku Tengah tentang Pedoman Penataan Saniri Negeri atau Badan Permusyawaratan Negeri, yang dalam Bab I; i dan j, dikatakan bahwa Negeri adalah kesatuan masyarakat hukum adat yang bersifat geneologis teritorial yang memiliki batas wilayah, berwenang mengatur dan mengurus kepentingan masyarakat setempat berdasarkan hak asal-usul dan adat istiadat setempat berada di Kabupaten Maluku Tengah yang diakui dan dihormati dalam Sistem Pemerintahan Negara Kesatuan Republik Indonesia; dan Pemerintah Negeri adalah penyelenggaraan urusan pemerintah oleh Pemerintah Negeri dan Saniri Negeri dalam mengatur dan mengurus kepentingan masyarakat setempat berdasarkan hak asal usul dan adat istiadat setempat dan diakui dan dihormati dalam sistem Pemerintahan Negara Kesatuan Republik Indonesia. Dan selanjutnya dalam Bab I; q dikatakan bahwa Saniri Negeri adalah lembaga/badan yang merupakan perwujudan demokrasi dalam penyelenggaraan pemerintahan Negeri dan sebagai unsur penyelenggara pemerintahan Negeri, berfungsi sebagai badan legislatif 
yang bersama-sama Kepala Pemerintahan Negeri membentuk Peraturan Negeri, mengawasi pelaksanaan tugas dari kepala Pemerintahan Negeri serta merupakan badan yang mendampingi kepala pemerintahan Negeri dalam memimpin Negeri sesuai tugas dan wewenang yang dimilikinya.

Saniri Negeri dibentuk sebagai mitra pemerintah di tingkat negeri untuk menyelenggarakan tugas dan wewenang negeri dengan tidak mengabaikan adat istiadat yang berlaku di negeri. Dalam Peraturan Daerah Kabupaten Maluku Tengah Nomor 04 Tahun 2006 Bab II Pasal 2 dan 3, tentang Pembentukan Saniri Negeri dan Badan Permusyawaratan Negeri mengatakan pada pasal 2:1) Saniri Negeri dibentuk di Negeri sebagai mitra Pemerintah Negeri dalam penyelenggaraan tugas dan wewenang Negeri; 3 ) Saniri Negeri dan Badan Permusyawaratan Negeri merupakan wahana demokrasi berdasarkan ketentuan peraturan perundang-undangan yang berlaku serta adat istiadat, hukum adat dan budaya setempat. Dan pada pasal 3 dikemukakan :1). Pembentukan Saniri Negeri ditetapkan dengan Peraturan Negeri; 2). Peraturan Negeri sebagaimana dimaksud dalam ayat (1) harus memperhatikan dengan sungguh-sungguh hak, asal usul, adat istiadat, budaya dan hukum adat setempat.

\subsection{Keanggotaan Saniri Negeri Suli}

Seperti lasimnya negeri-negeri di wilayah administrasi Maluku Tengah, keanggotaan Saniri Negeri mengacu pada Peraturan Daerah Kabupaten maluku Tengah Nomor 4 Tahun 2006, Pasal 11 dan 12 yang bahwa anggota Saniri merupakan wakil dari unsur masyarakat yang bersifat genelogis di negeri yang bersangkutan berdasarkan keterwakilan sesuai dengan adat istiadat, hukum adat dan budaya setempat, yang mana jumlah dari keanggotaan Saniri Negeri haruslah ganjil, dengan sekurang-kurangnya 5 orang dan sebanyak-banyaknya 11 orang yang wakil masyarakat yang mewakili unsur kewilayahaan, pemangku adat, golongan profesi, pemuka agama, dan juga berdasarkan jumlah penduduk yang dimiliki oleh negeri. Saat ini jumlah anggota Saniri Negeri Suli berjumlah 11 orang. Keanggotaan Saniri negeri Suli saat ini memang masih diakui masyarakat dan mereka juga masih melaksankan tugasnya, namun kenyataan masa jabatan mereka sudah berakhir, dan samapai saat ini belum ada pemilihan dan pengangkatan Saniri Negeri yang baru.

Keanggotaaan Saniri Negeri Suli merupakan representasi dari soa-soa yang ada, dimana masing-masing soa mewakilkan mataruma yang ada di dalamnya untuk duduk dalam Saniri Negeri. Pada Negeri Suli yang terdiri dari 4 (empat) soa, masing-masing 
soa ada keterwakilan dalam Saniri, dimana Soa Amalatuei diwakili oleh mataruma Pattisina, Sitanala dan Pattirane, Soa latusalamu yang diwakili oleh mataruma Salampessy dan Putinela, Soa Amarumahtena yang diwakili oleh mataruma Rering, Suitela, dan Waisapy, serta Soa Wainusalaut yang diwakili oleh mataruma, Lainsamputty, Manuputty, dan Haliwela. Berdasarkan data dan Informasi yang diperoleh mengatakan bahwa, mataruma-mataruma tersebut sudah dari dulu,. Turun temurun merupakan representase dari Soa-Soa yang ada di Negeri Suli.

Saat ini juga ada terjadi pembahasan yang cukup intens di Negeri suli terkait keanggotaan Saniri Negeri. Ada keinginan dari masyarakat untuk keanggotaan Saniri Negeri bukan merupakan keterwakilan dari Soa, tetapi harusnya merupakan keterwakilan dari mataruma (marga) yang di Negeri Suli berjumlah 15 (lima) belas marga.

Namun sampai dengan saat ini belum ada titik temu, karena ada sebahagian masyarakat Negeri Suli yang berkeinginan kalau keanggotaan Saniri harus tetap mengacu pada kebiasaan yang telah dilakukan sejak dulu, yakni keterwakilan dari Soa.

\subsection{Fungsi, Wewenang, Hak dan Kewajiban Saniri Negeri}

Peraturan Daerah Kabupaten Maluku Tengah Nomor 04 Tahun 2006 yang didasarkan atas persetujuan bersama Dewan Perwakilan Rakyat Daerah Kabupaten Maluku Tengah dan Bupati Maluku Tengah tentang Pedoman Penataan Saniri Negeri atau Badan Permusyawaratan Negeri telah mengatur dan menjelaskan tentang fungsi, wewenang, hak, dan kewajiban Saniri Negeri.

Sebagaimana diatur dalam Peraturan Daerah Kabupaten Maluku Tengah Nomor 04 Tahun 2006 Bab III Bagian Pertama Pasal 4 dan 6 dimana dikemukakan Saniri Negeri berfungsi: Pasal 4 (1). Saniri berkedudukan sejajar dan merupakan unsur penyelenggaraan Pemerintahan Negeri; (2) Saniri Negeri mempunyai fungsi a). menjaga, memelihara, mengayomi dan melestarikan adat istiadat, hukum adat dan budaya masyarakat di lingkungannya yang hidup, tumbuh dan berkembang; b). menampung dan menyalurkan aspirasi masyarakat; c). menetapkan Peraturan Negeri bersama-sama Kepala Pemerintah Negeri; dan d). melakukan pengawasan dan Penetapan Anggaran Pendapatan dan Belanja Negeri. (3). Pelaksanaan fungsi sebagaimana dimaksud dalam ayat (2) huruf a, dilakukan oleh Saniri Negeri bersama Kepala Pemerintah Negeri dan Kepala-Kepala Soa, yang mekanismenya ditetapkan dalam Peraturan Tata Tertib Saniri Negeri. Pasal 6 (1), Pelaksanaan lebih lanjut fungsi Saniri Negeri atau Badan Permusyawaratan Negeri 
sebagaimana dimaksud dalam Pasal 5 dan Pasal 6 Peraturan Daerah ini, diatur dengan Peraturan Tata Tertib Saniri Negeri atau Badan Permusyawaratan Negeri; (2). Peraturan Tata Tertib sebagaimana dimaksud dalam ayat (1) harus memperhatikan ketentuan perundang-undangan dan hukum adat setempat, dan sebelum dinyatakan berlaku harus terlebih dahulu dikonsultasikan dengan pihak Pemerintah Negeri/Negeri Administratif.

Peraturan Daerah Kabupaten Maluku Tengah Nomor 04 Tahun 2006 Bagian Kedua Pasal 7 juga mengemukakan bahwa (1) Saniri Negeri atau Badan Permusyawaratan Negeri, berwewenang: a). membahas rancangan Peraturan Negeri/Negeri Administratif bersama-sama Kepala Pemerintah Negeri/Negeri Administratif, b). melaksanakan pengawasan terhadap pelaksanaan Peraturan Negeri/Negeri Administartif dan Keputusan Kepala Pemerintah Negeri/Negeri Administartif; c). mengusulkan pengangkatan dan pemberhentian Kepala Pemerintah Negeri/Negeri Administratif; d). membentuk panitia pemilihan Kepala Pemerintah Negeri/Negeri Admnistartif; e). menggali, menampung, menghimpun, merumuskan dan menyalurkan aspirasi masyarakat; dan f). menyusun tata tertib Saniri Negeri atau Badan Permusyawaratan Negeri. (2). Selain wewenang sebagaimana dimaksud dalam ayat (1), Saniri Negeri dapat melaksanakan wewenang sesuai adat istiadat dan hukum adat setempat yang dilakukan bersama Kepala Pemerintah Negeri dan Kepala-Kepala Soa; (3). Pengaturan lebih lanjut ketentuan dalam ayat (2) diatur dalam Peraturan Tata Tertib Saniri Negeri.

Lebih lanjut tentang hak dan kewajiban Saniri Negeri pada Bab IV Pasal 8, 9, dan 10. Pasal 8 mengemukakan bahwa Saniri Negeri atau Badan Permusyawaratan Negeri mempunyai hak : a). meminta keterangan kepada pemerintah Negeri/Negeri Administratif; dan b). menyatakan pendapat. Selanjutnya pada Pasal 9 juga dikatakan bahwa anggota Saniri Negeri atau Badan Permusyawaratan Negeri mempunyai hak : a). mengajukan rancangan peraturan Negeri/Negheri Administratif; b). mengajukan pertanyaan; c). menyampaikan usul dan pendapat; d). memilih dan dipilih; dan e). memperoleh tunjangan,

Pada Pasal 10 juga dikatakan Anggota Saniri Negeri atau Badan Permusyawaratan Negeri mempunyai kewajiban: a). mengamalkan Pancasila, melaksanakan Undang-Undang Dasar Republik Indonesia Tahun 1945 dan mentaati segala peraturan perundang-undangan; b). melaksanakan kehidupan demokrasi dalam penyelenggaraan pemerintahan Negeri/Negeri Admnistratif; c). mempertahankan dan memelihara hukum nasional, hukum lokal termasuk hukum adat setempat serta keutuhan 
Negara Kesatuan Republik Indonesia; d). menyerap, menampung, menghimpun dan menindaklanjuti aspirasi masyarakat; e). memproses pemilihan Kepala Pemerintah Negeri/Negeri Administratif; f). mendahulukan kepentingan umum di atas kepentingan pribadi, kelompok dan golongan; g). menghormati nilai-nilai sosial budaya dan adat istiadat masyarakat setempat, dan h). menjaga norma dan etika dalam hubungan kerja dengan lembaga kemasyarakatan.

Berdasarkan hasil studi selama ini Saniri Negeri Suli belum dapat menjalankan fungsi, wewenang dan kewajibanya. Sampai saat ini belum ada produk peraturan yang dikeluarkan Saniri Negeri bersama Pemerintah Negeri belum ada produk peraturan yang dikeluarkan ataupun fungsi lainnya secara maksimal. Pada tahun 2018 memang sudah ada usulan peraturan negeri yang berkaitan dengan pemerintahan, namun sampai dengan saat ini belum disahkan. Ini memang sangat dipengaruhi dengan belum adanya pemerintah negeri (Raja) defenitif di Negeri Suli, bagitu juga dengan masa jabatan Saniri negeri itu sendiri.

\subsection{Eksistensi dan Peranan Saniri Negeri}

Eksistensi secara umum dipahami sebagai "keberadaan". Manusia sadar akan keberadaanya sebagai subjek yang menyadari atau sadar akan keberadaan dirinya (Ahmad, T. 2006 : 218-219). Manusia mencari makna keberadaan di dunia bukan pada hakikat manusia sendiri tetapi pada sesuatu yang berhubungan dengan dirinya.

Eksistensi berhubungan dengan peran yang dimainkan oleh setiap kehidupan manusia, dimana setiap manusia memilki peran sendiri-sendiri. Namun keberadaan kita dalam memainkan peranan sangat bergantung pada hubungan kita dengan orang lain dan lingkungan.

Sebagai makhluk sosial manusia tidak bisa hidup sendiri akan selalu ada saling ketergantungan antara manusia satu dengan lainnya. Apalagi keberadan dan keterlibatan manusia dalam organisasi dimana manusia menduduki peran dan fungsi yang wajib dilakukan.

Dalam hubungan antara manusia dalam organisasi kedudukan seseorang akan menentukan fungsi, kewenangan dan peran apa yang dilakoninya. Peranan (Role) merupakan proses dinamis kedudukan (status), dimana seseorang melaksanakan hak dan kewajibannya sesuai dengan kedudukannya, maka dia akan menjalankan suatu peran. Levinson dalam Soekanto (2009 : 213) mengemukanan peranan meliputi tiga hal : 1) peranan meliputi norma-norma yang dihubungkan dengan posisi atau tempat seseorang 
dalam masyarakat, yang berarti merupakan rangkaian peraturan-peraturan yang membimbing seseorang dalam kehidupan bermasyarakat; 2) peranan merupakan suatu konsep tentang apa yang dapat dilakukan oleh individu dalam masyarakat sebagai organisasi, dan 3) peranan sebagai perilaku individu yang penting bagi struktur sosial masyarakat.

Keberadaan dan peranan Saniri negeri yang adalah keterwakilan dari masyarakat negeri dan bagian dari pemerintahan negeri menempati posisi penting, karena dapat menentukan arah pembangunan yang hendak dicapai oleh masyarakat melalui Pemerintah Negeri. Untuk itu maka peranan tersebut harus diaplikasikan secara dinamis, sebagaimana yang dikatakan oleh Soerjono Soekanto, bahwa "peranan atau role merupakan aspek yang dinamis dari kedudukan atau status, dimana seseorang melaksanakan hak-hak dan kewajibannya sesuai dengan kedudukannya, maka ia telah melaksanakan suatu peran”. Ini berkaitan dengan Saniri Negeri dalam menjalankan tugas-tugas dan fungsinya diharapkan dapat memainkan perananya sesuai dengan aturan-aturan yang telah ditetapkan.

Dalam hal yang berhubungan dengan informasi Saniri juga harus memiliki peranan yang besar bagi kepentingan masyarakat maupun negeri itu sendiri. Dikatakan oleh Henry Minzberg dalam Miftah Thoha (2015), bahwa "peranan itu berhubungan dengan informasi (Information role), dimana peranan itu terdiri dari: a). Peranan sebagai monitor; b). Peranan sebagai desiminator; dan c). Peranan sebagai juru bicara.

Saniri Negeri juga harus dapat berperan sebagai negosiator terutama dalam memecahkan berbagai permasalahan yang dihadapi ataupun dalam menyalurkan aspirasi masyarakat ke Kepala Pemerintahan Negeri untuk dibahas secara bersama-sama. Dengan demikian apabila peranan ini dapat dilaksanakan dengan baik terutama dalam berbagai kegiatan pembangunan, maka pembangunan yang dilaksanakan akan mencapai target yang diharapkan.

Peranan Saniri Negeri dalam melaksanakan tugas dan fungsinya, dalam melayani, mengayomi aspirasi yang ada dimasyarakat akan turut menentukan arah pembangunan suatu negeri.

Dengan fungsi, wewenang, hak, dan kewajiban yang dimilki Saniri negeri, seharusnya dapat memainkan peran secara baik sesuai dengan yang diamanatkan oleh peraturan yang ada. 


\section{Kesimpulan.}

Saniri Negeri merupakan bagian dari pemerintah negeri yang sudah ada sejak dulu dan memiliki peran dalam struktur adat dan sistem pemerintahan di Maluku. Saniri negeri memiliki fungsi, wewenang, kewajiban yang harus dilaksanakan. Dengan adanya Peraturan Daerah Kabupaten Maluku Tengah Nomor 04 Tahun 2006 yang secara jelas telah mengatur tentang tugas dan fungsi, maka Saniri Negeri dapat mengoptimalkan peranannya dalam pemerintahan negeri. Sebagai representasi warga negeri dalam pemerintahan, Saniri bersamasama pemerintah negeri harus memperhatikan berbagai permasalahan yang terjadi di dalam negeri baik yang berupa kendala maupun potensi yang ada, serta membuat aturan-aturan yang dapat dijadikan pegangan dalam pengelolan berbagai sumberdaya yang menjadi dasar dalam pembangunan demi kemakmuran masyarakat dan kemajuan negeri.

Berdasarkan hasil dan pembahasan, Saniri negeri belum melaksanakan tugas, fungsi, kewenangan, dan kewajibannya dengan baik. Belum optimalnya Saniri dalam melakukan perannya, juga dapat dilihat dari kurangnya produktivitas saniri, dengan belum adanya pembahasan berkaitan dengan peraturan negeri bersama Pemerintah Negeri. Saniri Negeri belum dapat memainkan peranannya dalam menampung, menjaring menyalurkan aspirasi masyarakat terutama menyangkut pembangunan negeri agar apa yang benar-benar menjadi kebutuhan masyarakat dapat teratasi. Begitu juga dengan pengawasan, dan kewenangan serta fungsi lainnya yang menjadi tanggungjawabnya. Hal ini diakibatkan karena sampai dengan saat ini sudah kurang lebih 10 tahun belum ada pemerintahan negeri yang definitive. Begitu juga dengan masa jabatan keanggotaan saniri negeri yang telah berakhir. Meskipun demikian masyarakat negeri masih mengakui keberadaan saniri negeri, sehingga masih tetap berjalan dan melaksanakan tugasnya. 


\section{Daftar Pustaka}

Ahmad Tafsir, 2006, Filsafat Umum; Akal dan Hati Sejak Thales Sampai Capra, Bandung, Rosda karya,

Miftah Thoha, 2015, Kepemimpinan Dalam Manajemen, Jakarta, Raja Grafindo Persada

Moleong, L, 2006, Metode Penelitian Kualitatif, Bandung, Rosdakarya

Sitanala A, R, 2020, "Manajemen Pengelolaan Dana desa (Studi Kasus pada Negeri Suli, Kecamatan Salahutu, Kabupaten Maluku tengah)", FISIP Universitas Pattimura.

Soekanto, Soerjono, 2009, Sosiologi Suatu Pengantar. Jakarta, Penerbit Raja Grafindo

Soselisa, Pieter. S, 2010, Saniri Negeri Manifestasi Undang-Undang Nomor 32 Tahun 2004 (Studi Kasus Kecamatan Salahutu Kabupaten Maluku Tengah), Populis Jurnal Ilmu Sosial dan Ilmu Politik, Volume 4, No. 1, Maret 2010, Ambon, Fakultas Ilmu Sosial dan Ilmu Politik Universitas Pattimura. ISSN 1907-9893

Yabbar, R dan Ardi Hamzah, 2015, Tata Kelola Pemerintahan Desa, Dari Peraturan di Desa hingga Pengelolaan badan Usaha Milik Desa, Dari Perencanaan Pembangunan Dea hingga Pengelolaan Keuangan Desa, Surabaya, Penerbit Pustaka.

Ziwar Effendi, 1987, Hukum Adat Ambon-Lease, Jakarta, PT. Pradnya Paramita

Peraturan Daerah Kabupaten Maluku Tengah Nomor 01 Tahun 2006 Tentang Negeri

Peraturan Daerah Kabupaten Maluku Tengah Nomor 04 Tahun 2006 tentang Pedoman Penataan Saniri Negeri atau Badan Permusyawaratan Negeri 